\section{Cash bonuses won't stop brain drain, say Canadian academics}

Montreal

Quebec's provincial government may offer cash bonuses to researchers and academics, to try to stop them being wooed away by US institutions.

The provincial cabinet has formed a panel to study the brain drain. But research minister Jean Rochon, who leads the study group, says cash bonuses are not the only answer. He believes "a basket" of conditions is needed to keep researchers in Quebec.

Arpi Hamalian, president of the Quebec University Professors Federation, says bonuses won't compensate for years of university underfunding. A strategy to stop the brain drain should "restore the collegial environment that allows for good teaching and research; that means restoring funding," says the Concordia University education professor.

A study by the independent Conference Board of Canada says that official figures including only permanent emigrants underestimate the problem.

"Until 1989, the combined number of permanent and non-permanent Canadian emigrants to the United States was fairly stable at 17,000 annually," says the board. "By 1997, the number had increased to 98,000 , including a six-fold increase by non-permanent emigrants."

Researcher Mahmood Iqbal says the North American Free Trade Agreement changed the picture so that more than $\mathbf{9 0}$ per cent of US visas granted to Canadian professionals are now non-permanent, and that up to 60 per cent of the people holding them elect to stay permanently.

Prime Minister Jean Chrétien argues that the emigration of professionals is matched or exceeded by the inflow. But Iqbal says these are not comparable in quality, and it may take up to ten years for incomers to equal their Canadian counterparts' productivity. David Spurgeon

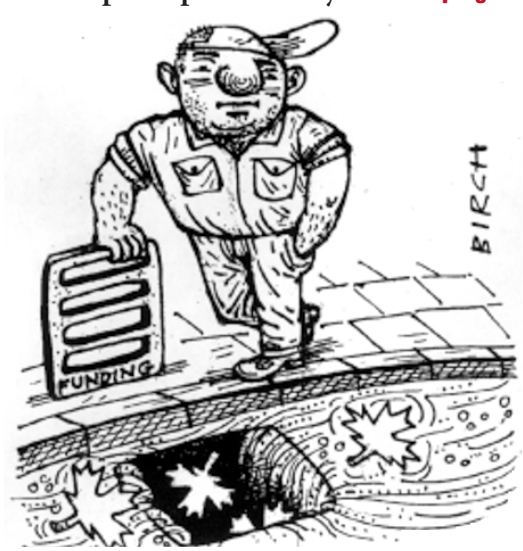

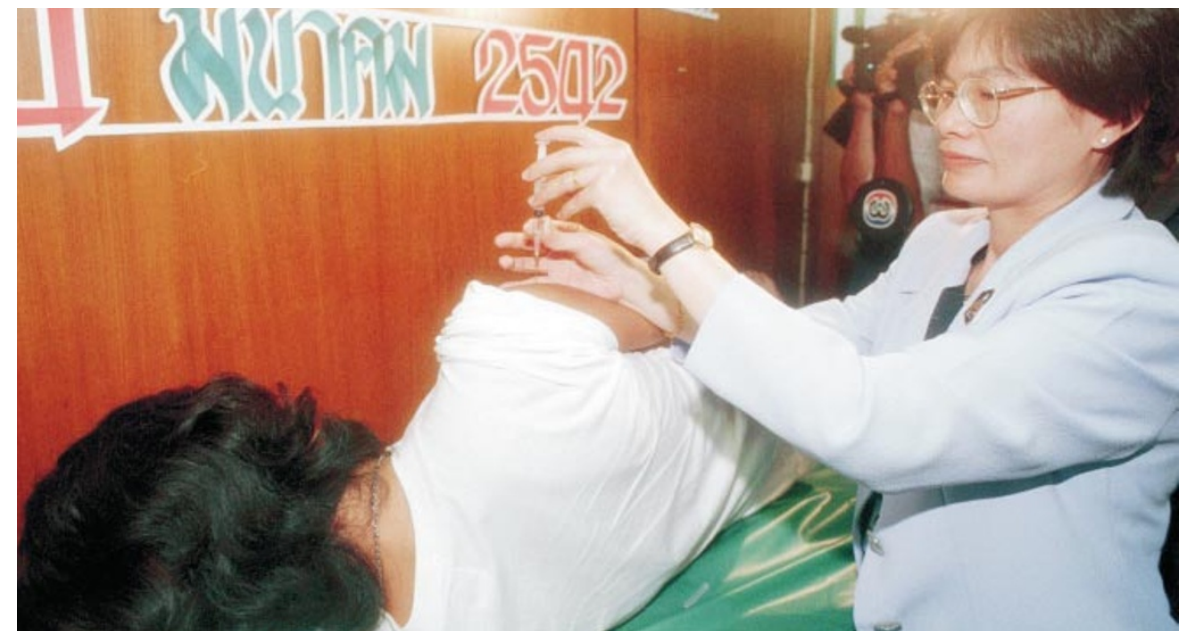

Lucky shot? A gp120 trial in Thailand is currently the world's only phase 3 AIDS vaccine trial.

\title{
Call for governments to back development of AIDS vaccine
}

Erice, Sicily

Scientists around the world will be asked to endorse a statement underlining the urgency of developing an AIDS vaccine and calling on governments - especially of poor countries - to be more actively involved.

The statement was drawn up at a two-day World Federation of Scientists workshop at the Ettore Majorana Centre for Scientific Culture in Erice, Sicily. Signatories already include two of the world's best-known AIDS researchers - Robert Gallo of the Institute of Human Virology in Baltimore, and Luc Montagnier, director of the World Foundation for AIDS Research and Prevention in Paris.

The workshop was told that vaccine development has consumed only 1 per cent of the US\$18 billion that has been spent fighting AIDS, and that only one full-scale phase 3 clinical trial is under way, with a vaccine using the gp120 protein in Thailand. A second trial is about to start in Uganda.

"Research into vaccine development has been disproportionately low compared to the potential public health benefits," says Seth Berkley, head of the New York-based International Aids Vaccine Initiative, which has been working to attract funds from bodies such as the World Bank and the Bill and Melinda Gates Foundation. "Even though research is now well supported, product development is not," he adds.

Scientists from poorer countries agree. "We need to get politicians on board at the highest level," says Fred Mhalu, head of Tanzania's anti-AIDS programme.

"In Brazil, AIDS activists have convinced the government to spend $\$ 600$ million on AIDS therapies," says Mauro Schechter, of the University of Rio de Janeiro. "But we still have difficulty in convincing officials of the need to provide funds for research on vaccines. There is still this feeling that vaccines are developed in the industrialized countries, whereas there is much that countries like Brazil can do, for example preparing the ground for efficacy trials, and perhaps eventually producing the vaccines themselves."

The authors of the Erice statement say it will help to increase awareness not only of the urgency and scientific feasibility of AIDS vaccine research, but of the many steps that developing countries can take.

Reflecting concern that some scientists may be reluctant to move into clinical trials without being confident of high levels of success, the statement says that the urgency "is such that even a partially effective vaccine would still be valuable in significantly reducing the rate at which HIV is spreading".

Recognizing that the biggest demand for a vaccine will be in developing countries so that it would be unlikely to produce substantial profits for manufacturers - the statement calls for new incentives to draw companies into public/private partnerships.

The authors of the statement hope that, if widely endorsed, it will help to increase political commitment to the national AIDS vaccine programmes that are now starting up in countries such as China, South Africa, Russia and Brazil, where the epidemic continues to grow rapidly.

They also hope to stimulate support from industrialized nations for international efforts, such as that led by the World Bank whose board will discuss a proposal for increased support of AIDS vaccine development later this month - and a joint initiative between UNAIDS and the World Health Organization, which is due to be launched early next year.

David Dickson 